\title{
PERFORMANCE OF SWEET POTATO CLONES FOR STARCH AND ETHANOL IN THREE REGIONS OF THE STATE OF SERGIPE, BRAZIL
}

\author{
DESEMPENHO DE CLONES DE BATATA DOCE PARA AMIDO E ETANOL EM \\ TRÊS REGIÕES DO ESTADO DE SERGIPE, BRASIL
}

\author{
Arie Fitzgerald BLANK ${ }^{1 *}$; Manoel Antônio de OLIVEIRA NETO \\ Roberta Pereira Miranda FERNANDES ${ }^{3}$; Thiago Matos ANDRADE ${ }^{4}$; \\ Alisson Marcel Souza de OLIVEIRA ${ }^{5}$; José Magno Queiroz LUZ ${ }^{6}$
}

1. Professor, Doutor, Departamento de Engenharia Agronômica, Universidade Federal de Sergipe - UFS, São Cristóvão, SE, Brasil. afblank@ufs.br; 2. Mestre em Agroecossistema, UFS, São Cristóvão SE, Brasil; 3. Professor, Doutor, Departamento de Fisiologia UFS, São Cristóvão, SE, Brasil, 4. Pesquisador do Programa de Pós-Graduação em Agricultura e Biodiversidade, Universidade Federal de Sergipe - UFS, São Cristóvão SE, Brasil; 5. Pesquisador do Programa de Pós-Graduação em Agricultura e Biodiversidade, Universidade Federal de Sergipe - UFS, São Cristóvão SE, Brasil; 6. Professor, Doutor, Universidade Federal de Uberlândia - UFU, Uberlândia-MG, Brasil.

\begin{abstract}
Sweet potato (Ipomoea batatas L.) is a species that belongs to the family Convolvulaceae, and is originated from Central America and South America. As the growing conditions have great influence on the crop, the determination of harvesting time may vary with the cultivar, the growing region, or with the type of consumption (in natura or industrial). The aim of this work was to evaluate the performance of Ipomoea batatas L. clones, cultivated in three regions in the state of Sergipe, for starch and ethanol production. Thirty-one sweet potato clones grown in three municipalities of the state of Sergipe were tested in a randomized block design. The following variables were analyzed: root dry matter content (RDMC), root starch content (SC), starch yield (SY), ethanol yield (EY), and ethanol yield per ton of root (EYR). EY values ranged from 5910.39 to $8516.12 \mathrm{~L} \mathrm{ha}^{-1}$; from 5141.85 to $6937.63 \mathrm{~L} \mathrm{ha}^{-1}$; and from 5829.62 to $8211.77 \mathrm{~L} \mathrm{ha}^{-1}$ in the municipalities of São Cristóvão, Malhador, and Canindé de São Francisco, respectively, for clones IPB-075 and IPB-087 and cultivar Palmas. Estimates of heritability $\left(\mathrm{h}^{2}\right)$ were above $50 \%$. The values of the ratio between the coefficient of genetic variation $\left(\mathrm{CV}_{\mathrm{g}}\right)$ and the coefficient of environmental variation $\left(\mathrm{CV}_{\mathrm{e}}\right)$ for $\mathrm{RDMC}, \mathrm{SC}$, and EYR were high.
\end{abstract}

KEYWORDS: Ipomoea batatas. Heritability. Biofuel. Genetic parameters

\section{INTRODUCTION}

Sweet potato (Ipomoea batatas L.) is a species that belongs to the family Convolvulaceae; it is originated from Central America and South America, and is grown from the Yucatan Peninsula, in Mexico, to Colombia and Brazil (SILVA et al., 2004). Despite being grown as an annual crop, sweet potato is a perennial, continuous tuber plant, and its natural death only occurs under severe weather conditions, such as frost, or long drought periods. Under ideal growing conditions, harvest begins at 90 days after planting. However, it can also occur between 120 and 150 days after planting, depending on the growing conditions, on the environmental conditions, and on the variety of sweet potato used (SILVA et al., 2002). Since the growing conditions greatly influence the crop, the determination of harvesting time may vary with the cultivar, with the growing region, or with the type of consumption (in natura or industrial). For industrial use, the species can be harvested later, since the primary interest is to obtain large quantities of dry matter and high carbohydrate levels, which results in higher yields for the industrial process (QUEIROGA et al., 2007).

Ethanol has been produced from starch since the 1970s; since then, scientists have been studying the use of starches for fuel, focusing on raw material yields for conversion into ethanol. While attempting to optimize glucose production from sweet potato starch, Ribeiro et al. (2009) observed that using high temperature and pressure was a more efficient method for acid hydrolysis than using water bath. Given that carbohydrates are converted into ethanol during fermentation, Pavlak et al., (2011) evaluated the efficiency of the fermentation process for hydrolyzed sweet potato using three Saccharomyces cerevisiae strains. The authors found that sweet potato used as raw material presented promising levels of viability, yield, and fermentation process efficiency for ethanol production.

With the expansion of renewable energy and biomass sources, this species has become an option for ethanol production in several regions of Brazil for being an easy-to-handle rustic plant with genetic diversity. Cavalcante et al. (2009) evaluated the 
productive and genetic potential of sweet potato clones and found that the indicators of production and yield for clones and varieties varied according to the environments, demonstrating the existence of promising materials for breeding programs.

Gonçalves Neto et al. (2011) evaluated sweet potato clones for different uses (human food, animal feed, and biofuel) in the municipality of Lavras, state of Minas Gerais, Brazil, and observed that eight clones were viable for use in ethanol production, showing that genotypes have genetic variability for different uses. In a study estimating the adaptability and stability of sweet potato genotypes in three environments in the SouthCentral region of the state of Tocantins, Brazil, Barreto et al. (2011) found that the clones presented adaptability in the studied environments for yield of roots.

Thus, it is important to study the phenotypic and genotypic parameters of the crop, as well as the behavior of these parameters according to the region. For this reason, the present study aimed to evaluate the performance of sweet potato clones for starch and ethanol in three regions of the state of Sergipe, Brazil.

\section{MATERIALS AND METHODS}

The experiments were carried out in three different regions of the state of Sergipe: Region 1 the "Campus Rural da UFS" Research Farm of the
Federal University of Sergipe, located in the municipality of São Cristóvão, state of Sergipe, in the central portion of the physiographic region of the coast of the state of Sergipe (lat. 10 $0^{\circ} 55^{\prime 27} " \mathrm{~S}$, long. $37^{\circ} 12^{\prime} 01^{\prime \prime} \mathrm{W}$, at $46 \mathrm{~m}$ asl); Region 2 - the Dandara settlement project, located in the municipality of Malhador, state of Sergipe, in the Central portion of the agreste region of the state of Sergipe (lat. $10^{\circ} 42^{\prime} 37.4^{\prime \prime} \mathrm{S}$, long. $37^{\circ} 16^{\prime} 05.8^{\prime \prime} \mathrm{W}$, at $35 \mathrm{~m}$ asl); and Region 3 - the Jacaré-Curituba settlement project, located in the municipality of Canindé de São Francisco, state of Sergipe, in the North-West region of the state of Sergipe, on the right bank of the São Francisco River (lat. 09³8'40.1" S, long. 37²37'16.1" W, at $68 \mathrm{~m}$ asl).

The clones tested in the three environments were obtained from the Active Germplasm Bank (AGB) of the Federal University of Sergipe, as described in Table 1. The commercial cultivars Brazlândia Branca, Brazlândia Rosada, and Palmas were used as controls. Vegetative branches with eight to 12 internodes $(25 \mathrm{~cm})$ were selected for planting from the population of clones of the AGB of the Federal University of Sergipe, properly identified, and transported to the planting site. Prior to planting, branches had been watered to prevent loss of branches due to dehydration. In the experimental area, branches were planted at 10-15 $\mathrm{cm}$ depth, and a portion containing three to four nodes was buried, and subsequently watered.

Table 1. Description of the 31 evaluated sweet potato clones and their identifications in the Active Germplasm Bank (Banco Ativo de Germoplasma - BAG) of the Federal University of Sergipe (Universidade Federal de Sergipe - UFS), Brazil: code, site of origin, municipality, and name.

\begin{tabular}{ccccc}
\hline UFS code & \multicolumn{1}{c}{ Site of origin } & Municipality & State & Code/Name of origin \\
\hline IPB-007 & Federal University of Lavras & Lavras & Minas Gerais & UFLA-07-12 \\
IPB-011 & Federal University of Lavras & Lavras & Minas Gerais & UFLA-07-49 \\
IPB-014 & Federal University of Lavras & Lavras & Minas Gerais & 2007HSF001-09 \\
IPB-023 & Federal University of Lavras & Lavras & Minas Gerais & 2007HSF001-28 \\
IPB-037 & Federal University of Lavras & Lavras & Minas Gerais & UFLA-07-43 \\
IPB-038 & Federal University of Lavras & Lavras & Minas Gerais & 2007HSF002-19 \\
IPB-052 & Federal University of Lavras & Lavras & Minas Gerais & Brazlândia Branca \\
IPB-053 & Federal University of Lavras & Lavras & Minas Gerais & Palmas \\
IPB-054 & Federal University of Lavras & Lavras & Minas Gerais & 2007HSF007-16 \\
IPB-056 & Federal University of Lavras & Lavras & Minas Gerais & 2007HSF007-21 \\
IPB-060 & Federal University of Lavras & Lavras & Minas Gerais & Brazlândia Rosada \\
IPB-065 & Federal University of Lavras & Lavras & Minas Gerais & 2007HSF005-01 \\
IPB-072 & Federal University of Lavras & Lavras & Minas Gerais & 2007HSF010-23 \\
IPB-073 & Federal University of Lavras & Lavras & Minas Gerais & 2007HSF010-25 \\
IPB-075 & Federal University of Lavras & Lavras & Minas Gerais & 2007HSF010-31 \\
IPB-077 & Federal University of Lavras & Lavras & Minas Gerais & 2007HSF010-08 \\
IPB-079 & Federal University of Lavras & Lavras & Minas Gerais & 2007HSF010-33 \\
IPB-080 & Federal University of Lavras & Lavras & Minas Gerais & 2007HSF010-35 \\
IPB-087 & Federal University of Lavras & Lavras & Minas Gerais & 2007HSF011-06
\end{tabular}




$\begin{array}{cc}\text { IPB-091 } & \text { Federal University of Lavras } \\ \text { IPB-095 } & \text { Federal University of Lavras } \\ \text { IPB-099 } & \text { Federal University of Lavras } \\ \text { IPB-114 } & \text { Federal University of Lavras } \\ \text { IPB-137 } & \text { Federal University of Lavras } \\ \text { IPB-145 } & \text { Dandara settlement } \\ \text { IPB-147 } & \text { Small farmer } \\ \text { IPB-149 } & \text { Small farmer } \\ \text { IPB-151 } & \text { Small farmer } \\ \text { IPB-158 } & \text { Small farmer } \\ \text { IPB-159 } & \text { Small farmer } \\ \text { IPB-162 } & \text { Jacaré - Curituba settlement }\end{array}$

The nutrient requirements of the crops were calculated based on physical and chemical soil analyses (Table 1). At 30 days before planting, the municipalities of São Cristóvão and Malhador were limed at $2 \mathrm{~T} \mathrm{ha}^{-1}$, and the plot was fertilized with NPK (16 g plant ${ }^{-1}$ NPK 6-24-12). After planting,

$\begin{array}{cc}\text { Lavras } & \text { Minas Gerais } \\ \text { Lavras } & \text { Minas Gerais } \\ \text { Lavras } & \text { Minas Gerais } \\ \text { Lavras } & \text { Minas Gerais } \\ \text { Lavras } & \text { Minas Gerais } \\ \text { Malhador } & \text { Sergipe } \\ \text { Moita Bonita } & \text { Sergipe } \\ \text { Moita Bonita } & \text { Sergipe } \\ \text { Moita Bonita } & \text { Sergipe } \\ \text { Remijo } & \text { Paraiba } \\ \text { Heliopólis } & \text { Bahia } \\ \text { Poço Redondo } & \text { Sergipe }\end{array}$

2007HSF012-02

2007HSF016-05

2007HSF020-07

2007HSF022-19

2007HSF028-08

Roxa escura

Italiana

Ourinho

Roxa carregadeira Granfina

Ourinho baiana

Jacarezinho

Table 2. Results of the chemical and physical soil analysis of the experimental areas of São Cristóvão,

\begin{tabular}{|c|c|c|c|c|c|c|}
\hline \multirow[t]{2}{*}{ Physical-chemical characteristics } & \multicolumn{2}{|c|}{ São Cristóvão } & \multicolumn{2}{|c|}{ Malhador } & \multicolumn{2}{|c|}{$\begin{array}{l}\text { Canindé do São } \\
\text { Francisco }\end{array}$} \\
\hline & Results & Interpretation & Results & Interpretation & Results & Interpretation \\
\hline pH (water) & 5.40 & Middle & 5.58 & Middle & 7.12 & High \\
\hline Organic matter (dag. $\left.\mathrm{dm}^{-3}\right)$ & 0.86 & Low & 11.6 & High & 14.6 & High \\
\hline $\begin{array}{l}\text { Calcium + Magnesium } \\
\left(\text { cmolc. } \mathrm{dm}^{-3}\right)\end{array}$ & 0.82 & Low & 3.52 & Middle & 27.2 & High \\
\hline Calcium $\left(\mathrm{cmolc} \cdot \mathrm{dm}^{-3}\right)$ & 0.39 & Low & 2.06 & Middle & 19.4 & High \\
\hline Magnesium (cmolc.dm ${ }^{-3}$ ) & 0.43 & Middle & 1.46 & High & 7.80 & High \\
\hline Aluminum (cmolc. $\left.\mathrm{dm}^{-3}\right)$ & 0.65 & Middle & $<0.08$ & Low & $<0.08$ & Low \\
\hline $\begin{array}{l}\text { Hydrogen + Aluminum } \\
\left(\mathrm{cmolc}^{\left.-\mathrm{dm}^{-3}\right)}\right.\end{array}$ & 2.03 & - & 2.03 & - & ND & - \\
\hline Sodium $\left(\mathrm{mg} \cdot \mathrm{dm}^{-3}\right)$ & 3.5 & - & 0.131 & - & 40.0 & - \\
\hline Potassium (mg. $\left.\mathrm{dm}^{-3}\right)$ & 21.1 & Low & 45.1 & Middle & 124. & High \\
\hline Phosphor (mg. $\mathrm{dm}^{-3}$ ) & 7.0 & Low & 18.7 & Middle & 16.1 & High \\
\hline SB $\left(\right.$ cmolc. $\left.\mathrm{dm}^{-3}\right)$ & 0.89 & - & 3.77 & - & 27.7 & - \\
\hline CTC $\left(\mathrm{cmolc} \cdot \mathrm{dm}^{-3}\right)$ & 2.92 & Low & 5.80 & Middle & 27.7 & High \\
\hline $\operatorname{PST}(\%)$ & 0.51 & - & 2.26 & - & 0.63 & - \\
\hline $\mathrm{V}(\%)$ & 30.5 & Low & 65.0 & Middle & 100 & High \\
\hline Iron $\left(\mathrm{mg} . \mathrm{L}^{-1}\right)$ & 329.61 & Adequate & & - & & - \\
\hline Copper (mg. $\left.\mathrm{L}^{-1}\right)$ & 10.44 & Adequate & & - & & - \\
\hline Manganese (mg. $\left.\mathrm{L}^{-1}\right)$ & 0.76 & Low & & - & & - \\
\hline Zinc (mg. $\left.\mathrm{L}^{-1}\right)$ & 7.07 & Adequate & & - & & - \\
\hline Granulometry - Sand (\%) & 73.82 & - & 62.56 & - & 30.56 & - \\
\hline Granulometry - Clay (\%) & 5.46 & - & 7.47 & - & 25.47 & - \\
\hline Granulometry - Silte (\%) & 20.72 & - & 29.97 & - & 43.97 & - \\
\hline Textural classification & $\begin{array}{l}\text { Sandy } \\
\text { franc }\end{array}$ & - & $\begin{array}{l}\text { Sandy } \\
\text { franc }\end{array}$ & - & $\begin{array}{l}\text { Sandy } \\
\text { franc }\end{array}$ & - \\
\hline
\end{tabular}

Plowing and disking were carried out for soil preparation. Ridges were made manually with a hoe. Cultural practices were applied when necessary, according to the recommendations for the topdressing was applied monthly, using the same formula, but at $12 \mathrm{~g}$ plant $^{-1}$. The amount of fertilizer varied according to the soil analyses for each site (Table 2), with a dose of $8 \mathrm{~g} \mathrm{plant}^{-1}$ at planting, and $6 \mathrm{~g} \mathrm{\text {plant } ^ { - 1 }}$ as monthly topdressing, in the municipality of Canindé de São Francisco.

\section{Malhador and Canindé do São Francisco, at 0-20 cm depth.} . 
Root dry matter content (RDMC): Obtained by placing $10 \mathrm{~g}$ of freshly grated root from each plot in a forced air circulation drying oven, at $105^{\circ} \mathrm{C}$, until constant weight. RDMC was calculated using the formula:

\section{$R D M C=(R D M / R F M) \times 100$}

Where $R D M C$ is the root dry matter content, $R D M$ is the weight of root dry matter, and $R F M$ is the weight of root fresh matter;

Root starch content (SC): Obtained by the Lane-Eynon method (INSTITUTO ADOLFO LUTZ, 2005). The method is based on reducing a known volume of an alkaline copper reagent (Fehling) to cuprous oxide;

Starch yield (SY): Obtained by multiplying the starch content by the total root yield, and expressed in $\mathrm{T} \mathrm{ha}^{-1}$;

Ethanol yield $(E Y)$ : Obtained by multiplying the starch yield by the conversion factor 1.0858, according to Pavlak et al., (2011), and expressed in $\mathrm{L} \mathrm{ha}^{-1}$;

Ethanol yield per ton of root (EYR): Obtained by dividing the EY by the total root yield, and expressed in $\mathrm{L} \mathrm{ton}^{-1}$;

For each site, the experimental design consisted of randomized blocks with three replications. Each plot consisted of a $0.40 \mathrm{~m}$ ridge of 10 plants, spaced $0.80 \mathrm{~m}$ between ridges and 0.40 $\mathrm{m}$ between plants. IPB-149 clone was planted (local cultivar) as border, surrounding the experiment.

The variables were subjected to joint analysis of variance, according to the model proposed by Vencovsky \& Barriga, (1992), considering the effects of environments and genotypes as random, using the software GENES.

The following mathematical model was used:

$$
Y_{i j k}=m+B / A_{j k}+G_{i}+A_{j}+G A_{i j}+E_{i j k}
$$

where $Y_{i j k}$ is the observed value of the $\mathrm{i}^{\text {th }}$ genotype, in the $\mathrm{k}^{\text {th }}$ block, within the $\mathrm{j}^{\text {th }}$ environment; $m$ is the overall mean; $B / A_{j k}$ is the effect of the $\mathrm{k}^{\text {th }}$ block within the $\mathrm{j}^{\text {th }}$ environment; $G_{i}$ is the effect of the $\mathrm{i}^{\text {th }}$ genotype; $A_{j}$ is the effect of the $\mathrm{j}^{\text {th }}$ environment; $G A_{i j}$ is the effect of the interaction between the $\mathrm{i}^{\text {th }}$ genotype and the $\mathrm{j}^{\text {th }}$ environment; and $E_{i j k}$ is the experimental error.

Genetic and phenotypic parameters, such as heritability $\left(\mathrm{h}^{2}\right)$, coefficient of variation $(\mathrm{CV})$, and phenotypic and genotypic correlations were estimated using the GENES software (Cruz 2006). The Scott-Knott test was used for means clustering, at 5\% probability, using the SISVAR software, version 5.0.

Based on the expected mean squares, the genetic $\left(\sigma_{g}^{2}\right)$ and environmental $\left(\sigma_{e}^{2}\right)$ variance components were estimated for the primary evaluated traits. Genetic parameters were also estimated, which included the coefficient of heritability $\left(\mathrm{h}^{2}\right)$ and the ratio between the CV of genetic variation and the $\mathrm{CV}$ of environmental variation $\left(\mathrm{CV}_{\mathrm{g}} / \mathrm{CV}_{\mathrm{e}}\right)$.

$$
\begin{aligned}
\sigma_{f}^{2} & =\sigma_{g}^{2}+\sigma_{g}^{2}+\sigma_{g g}^{2} \\
\sigma_{g}^{2} & =\frac{Q M_{G}-Q M_{G A}}{a r} \\
\sigma_{g e}^{2} & =\frac{Q M_{G A}-Q M_{R}}{r} \times \frac{g-1}{g} \\
h^{2} & =\frac{\sigma_{g}^{2}}{G M_{G} / a r} \\
C V_{g} & =\frac{100 \sqrt{\sigma_{g}^{2}}}{m}
\end{aligned}
$$

\section{RESULTS AND DISCUSSION}

Differences between treatments $(\alpha=0.05)$ were observed for all the evaluated traits: root dry matter content (RDMC), root starch content (SC), starch yield (SY), ethanol yield (EY), and ethanol yield per ton of root (EYR) (Tables 3 and 4). Differences were also observed for joint analysis and genetic parameters (Tables 5 and 6).

Root dry matter content (RDMC)

For the municipality of São Cristóvão, three groups were formed for RDMC, with values ranging from $29.72 \%$ to $44.05 \%$. IPB-159 clone had RDMC value $(44.05 \%)$ higher than those found in the controls Brazlândia Branca and Brazlândia Rosada (Table 3).

For the municipality of Malhador, two groups were formed for RDMC, with values ranging from $24.26 \%$ to $36.82 \%$ (Table 3 ). IPB-162 clone had RDMC value $(36.82 \%)$ similar to that of the control Brazlândia Rosada (Table 3).

For the municipality of Canindé de São Francisco, also two groups were formed for RDMC, with values ranging from $26.74 \%$ to $40.48 \%$ (Table 3). Clones IPB-162 (38.59\%) and IPB-149 (40.48\%) had RDMC values higher than those found in the controls Brazlândia Branca and Brazlândia Rosada (Table 3). 
Table 3. Mean values for content of root dry matter, root starch and starch yield for 31 sweet potato clones grown in three municipalities of the state of Sergipe, Brazil.

\begin{tabular}{|c|c|c|c|c|c|c|c|c|c|}
\hline \multirow[b]{2}{*}{ Clones } & \multicolumn{3}{|c|}{ Root dry matter content $(\%)$} & \multicolumn{3}{|c|}{ Root starch content (\%) } & \multicolumn{3}{|c|}{ Starch yield $\left(\mathrm{T} \mathrm{ha}^{-1}\right)$} \\
\hline & $\mathrm{SC}$ & MA & CA & $\mathrm{SC}$ & MA & CA & $\mathrm{SC}$ & MA & CA \\
\hline IPB-007 & $.28 \mathrm{bA}$ & $7.52 \mathrm{bA}$ & $.15 \mathrm{bA}$ & $7.05 \mathrm{cA}$ & $4.95 \mathrm{eA}$ & $62 \mathrm{eB}$ & $47 \mathrm{aA}$ & $2.77 \mathrm{bB}$ & $3.25 \epsilon$ \\
\hline & & & & & & & & & $3.15 \mathrm{eA}$ \\
\hline & & & & & 21 & & $6 \mathrm{bB}$ & 5.0 & $10.75 \mathrm{aA}$ \\
\hline IPB-023 & & & & & & & $5.17 \mathrm{aB}$ & $2.76 \mathrm{bC}$ & 9.1 \\
\hline IPB-037 & & & & & & & & & \\
\hline IPB- & & & & & & & & & \\
\hline azlândi & & & & & 12.3 & & $5.97 \mathrm{aA}$ & & \\
\hline Palmas & & A & & $27.26 \mathrm{aA}$ & $22.56 \mathrm{cB}$ & & & & \\
\hline IP & & & & & 17.4 & & & & dA \\
\hline IPB & & & & & & & & & \\
\hline "lît & & B & & & 17. & & $\mathrm{aA}$ & & \\
\hline & & & & & & & & & \\
\hline & & & & & & & & & \\
\hline & & & & & & & & & \\
\hline & & & & & & & & & \\
\hline & & & & & & & & & $11.05 \mathrm{aA}$ \\
\hline & & & & & & & & & \\
\hline & & & & & & & $3.90 \mathrm{aB}$ & 2.3 & \\
\hline & & & & & & & & & \\
\hline & & & & & & & & & \\
\hline & & & & & & & & $4.52 \mathrm{aA}$ & \\
\hline & & & & & & & $4.39 \mathrm{bA}$ & $4.32 \mathrm{aA}$ & \\
\hline & & & & & & & $6.12 \mathrm{aA}$ & $2.49 \mathrm{bB}$ & \\
\hline & & & & & & & $2.28 \mathrm{bB}$ & & \\
\hline & & & & & & & 3.1 & $5.40 \mathrm{aA}$ & \\
\hline & & & & & & & 5.1 & & \\
\hline & & & & & & & 4.7 & & \\
\hline & & & & & 15 . & & 5.5 & & \\
\hline & & & & & & & & & \\
\hline & & & & & 26. & & 2.07 & 2.7 & \\
\hline & $\mathrm{aA}$ & 36. & $38.59 \mathrm{aA}$ & $23.32 \mathrm{aB}$ & $28.58 \mathrm{aA}$ & $13.88 \mathrm{dC}$ & $6.38 \mathrm{aA}$ & $3.86 \mathrm{aB}$ & $3.40 \mathrm{eB}$ \\
\hline $\mathrm{CV}(\%)$ & 9.28 & 12.02 & 5.49 & 9.43 & 12.32 & 6.51 & 21.50 & 27.05 & 25.97 \\
\hline
\end{tabular}

Means followed by the same lowercase letter in the columns and uppercase letter in the rows do not significantly differ by the ScottKnott test $(p \leq 0.05) ; \mathrm{SC}=$ São Cristóvão; MA = Malhador; CA = Canindé do São Franscisco.

Comparing the results found in each municipality, RDMC values in São Cristóvão were higher than those found by Silveira (2004), who evaluated nine sweet potato cultivars, and observed a range of RDMC values from $28.56 \%$ to $40.44 \%$ in cultivars recommended for use in bioenergy production. Vieira et al. (2015) found similar results, with values of RDMC ranging from $25.12 \%$ to $37.67 \%$. This shows that different genotypes present different responses to RDMC, depending on the environment where they are grown. In the municipality of Malhador, RDMC values were lower than those found by Silveira (2004), and similar to those found in the municipality of Canindé de São Francisco.

\section{Root starch content (SC)}

In the municipality of São Cristóvão, clones had different SC values and formed four distinct groups. Clones IPB-162, IPB-158, IPB-149, and the control cultivar Palmas presented SC values of $23.32 \%, 24.63 \%, 25.64 \%$, and $27.26 \%$, respectively (Table 3), which were higher than those found for the other cultivars. These materials have proved to be promising, demonstrating the importance of competitive trials in multiple environments. SC values of the other treatments ranged from $11.47 \%$ to $22.60 \%$ (Table 3 ).

Differences were observed among treatments of the municipality of Malhador. Five groups were formed, and IPB-162 (26.06\%), IPB$159(28.58 \%)$, and IPB-056 (24.16\%) presented the 
highest starch levels (Table 3). The values for this variable ranged from $15.05 \%$ to $22.56 \%$ in the other treatments (Table 3 ).

In the municipality of Canindé de São Francisco, IPB-014 and IPB-149 clones had the highest values $(27.50 \%$ and $27.04 \%$, respectively) (Table 3). In the other clones, SC values ranged from $9.67 \%$ to $24.10 \%$ (Table3).

In the municipalities of São Cristóvão and Malhador, SC values were generally higher than those found by (SILVEIRA, 2004), and the clones with the highest means were only surpassed by the cultivar Carolina Vitória, which had SC value of $30.20 \%$. SC values found in the municipality of Canindé de São Francisco, where most of the clones had means above 30\%, were higher than those found by Silveira (2004).

\section{Starch yield (SY)}

A large group was formed for the SY values obtained for the municipality of São Cristóvão, which consisted of the clones IPB-007, IPB-023, IPB-037, IPB-038, IPB-056, IPB-073, IPB-075, IPB-079, IPB-080, IPB-087, IPB-095, IPB-114, IPB-147, IPB-149, IPB-151, IPB-158, and IPB-162, and the controls Brazlândia Branca, Palmas, and Brazlândia Rosada (Table 3). In this group, SY values were higher than $5 \mathrm{~T} \mathrm{ha}^{-1}$, particularly for the control Palmas, which presented SY value of $7.56 \mathrm{~T}$ $\mathrm{ha}^{-1}$, and for IPB-038 clone, which presented SY value of 7.28 T ha- ${ }^{-1}$ (Table 3). For the other clones, $\mathrm{SY}$ values varied between $2.07 \mathrm{~T} \mathrm{ha}^{-1}$ and $4.96 \mathrm{~T}^{-}$ 1 .

For the municipality of Malhador, two distinct groups were formed. The group consisting of the clones IPB-014, IPB-075, IPB-079, IPB-087, IPB-137, and IPB-145 and the controls Brazlândia Rosada and Palmas presented the highest SY values, particularly IPB-087 clone, with SY value of $6.38 \mathrm{~T}$ $\mathrm{ha}^{-1}$ (Table 3). The other group had SY values ranging between $1.35 \mathrm{~T} \mathrm{ha}^{-1}$ and $4.52 \mathrm{~T} \mathrm{ha}^{-1}$ (Table $3)$.

For the municipality of Canindé de São Francisco, five groups were formed. The group consisting of the clones IPB-014 and IPB-077 presented the highest $S Y$ values, which were greater than $10 \mathrm{~T} \mathrm{ha}^{-1}$, especially the IPB-077 clone, with SY value of $11.05 \mathrm{~T} \mathrm{ha}^{-1}$ (Table 3). For the other four groups, mean SY values varied between $2.59 \mathrm{~T}$ $\mathrm{ha}^{-1}$ and $9.34 \mathrm{~T} \mathrm{ha}^{-1}$ (Table 3).

SY values found in the three municipalities were lower than those obtained by Silveira (2004), using cultivar Carolina Vitoria $\left(22.55 \mathrm{~T} \mathrm{ha}^{-1}\right)$; and by Castro et al. (2011), using cultivar Amanda $\left(30.17 \mathrm{~T} \mathrm{ha}^{-1}\right)$.

\section{Ethanol yield (EY)}

For EY in São Cristóvão, a large group was formed, consisting of the clones IPB-007, IPB-023, IPB-037, IPB-038, IPB-056, IPB-073, IPB-075, IPB-079, IPB-087, IPB-095, IPB-114, IPB-147, IPB-149, IPB-151, IPB-158, IPB-159, and IPB-162 and the controls Brazlândia Branca, Palmas, and Brazlândia Rosada (Table 4). The EY values of this group ranged from $5105.24 \mathrm{~L} \mathrm{ha}^{-1}$ to $8211.77 \mathrm{~L} \mathrm{ha}^{-1}$; IPB-007, IPB-038, Palmas, and IPB-056 had EY means higher than $7000 \mathrm{~L} \mathrm{ha}^{-1}$. For the remaining clones, EY means ranged from $2249.11 \mathrm{~L} \mathrm{ha}^{-1}$ to 4773.71 L ha' (Table 4).

Two groups were formed in Malhador. The group consisting of the clones IPB-014, IPB-075, IPB-079, IPB-137, and IPB-139 and the control Brazlândia Rosada presented the highest mean value for EY (Table 4). The values found in this group ranged from $5436.75 \mathrm{~L} \mathrm{ha}^{-1}$ to $6937.63 \mathrm{~L} \mathrm{ha}^{-1}$. For the other groups, EY means ranged between 1475.64 $\mathrm{L} \mathrm{ha}^{-1}$ and 4913.93 L ha ${ }^{-1}$ (Table 4).

For Canindé de São Francisco, five groups were formed; IPB-014 and IPB-077 differed from the other clones, with EY means of $11672.12 \mathrm{~L} \mathrm{ha}^{-1}$ and 11998.56 $\mathrm{L} \mathrm{ha}^{-1}$, respectively (Table 4). For the remaining clones, EY means varied between 2821.55 $\mathrm{L} \mathrm{ha}^{-1}$ and 10146.06 L ha ${ }^{-1}$ (Table 4).

For the municipalities of São Cristóvão and Malhador, results were similar to those found by Castro et al. (2011), who obtained SY values of 46.7 $\mathrm{T} \mathrm{ha}^{-1}$ and $32.17 \mathrm{~T} \mathrm{ha}^{-1}$, and EY values of $9545.48 \mathrm{~L}$ $\mathrm{ha}^{-1}$ and $6866.68 \mathrm{~L} \mathrm{ha}^{-1}$, for the cultivars Amanda and Carolina Vitoria, respectively. However, when comparing the results of the same study with the values found in Canindé de São Francisco, in the present study, the latter exhibited higher values than those found by Castro et al. (2011) (EY values higher than $10000 \mathrm{~L} \mathrm{ha}^{-1}$ ).

\section{Ethanol yield per ton of root (EYR)}

In the municipality of São Cristóvão, four groups were formed. The group consisting of the clones IPB-149, IPB-158, and IPB-162, and the control Palmas, presented the highest EYR values (Table 4). In this group, cultivar Palmas and IPB149 clone stood out with EYR value of $296.05 \mathrm{~L}$ ton $^{-1}$ and278.49 $\mathrm{L} \mathrm{ton}^{-1}$, respectively. The remaining clones had EYR means ranging from 124.53 $\mathrm{L} \mathrm{ton}^{-1}$ to $245.39 \mathrm{~L} \mathrm{ton}^{-1}$ (Table 4).

In Malhador, five groups were formed. The clones obtained EYR values between 134.40 $\mathrm{L} \mathrm{ton}^{-1}$ and 310.42 $\mathrm{L} \mathrm{ton}^{-1}$ (Table 4).

In the municipality of Canindé de San Francisco, five groups were also formed. IPB-014 and IPB-162 clones had the highest EYR means, of 
298.61 $\mathrm{L} \mathrm{ton}^{-1}$ and $293.70 \mathrm{~L} \mathrm{ton}^{-1}$, respectively (Table 4). The clones presented EYR values ranging from 105.09 $\mathrm{L}^{-1}$ to $^{-1}$ to $298.61 \mathrm{~L}^{-1}$ (Table 4). EYR values for the municipalities of São Cristóvão and Canindé de São Francisco were higher than those found by (PAVLAK et al., 2011), who analyzed cultivar Duda for the same variable, and found EYR value of $161 \mathrm{~L} \mathrm{ton}^{-1}$. However, for the municipality of Malhador, results were lower than those observed in the study of Pavlak et al. (2011).

Table 4. Mean values for ethanol yield and ethanol per ton of root for the 31 sweet potato clones grown in three municipalities of the state of Sergipe, Brazil.

\begin{tabular}{|c|c|c|c|c|c|c|}
\hline \multirow[b]{2}{*}{ Clones } & \multicolumn{3}{|c|}{ Ethanol yield $\left(\mathrm{L} \mathrm{ha}^{-1}\right)$} & \multicolumn{3}{|c|}{ Ethanol per ton of root $\left(\mathrm{L} \mathrm{ton}^{-1}\right)$} \\
\hline & $\mathrm{SC}$ & MA & CA & $\mathrm{SC}$ & MA & $\mathrm{CA}$ \\
\hline IPB-007 & $7030.66 \mathrm{aA}$ & $3013.54 \mathrm{bB}$ & $3532.32 \mathrm{eB}$ & $185.14 \mathrm{cA}$ & $162.40 \mathrm{eA}$ & $115.41 \mathrm{eB}$ \\
\hline IPB-011 & $2474.34 \mathrm{bA}$ & $2780.27 \mathrm{bA}$ & $3426.57 \mathrm{eA}$ & $197.94 \mathrm{cA}$ & $199.02 \mathrm{dA}$ & $128.71 \mathrm{aB}$ \\
\hline IPB-014 & $3975.26 \mathrm{bB}$ & $5436.75 \mathrm{aB}$ & 11672.12aA & $245.39 \mathrm{bB}$ & $228.42 \mathrm{cB}$ & $298.61 \mathrm{aA}$ \\
\hline IPB-023 & $5617.27 \mathrm{aB}$ & 2998.58 bC & 9931.38 bA & $165.48 \mathrm{~dB}$ & $190.22 \mathrm{dA}$ & $205.94 \mathrm{cA}$ \\
\hline IPB-037 & $5928.81 \mathrm{aA}$ & $1951.14 \mathrm{bB}$ & $6141.71 \mathrm{dA}$ & $162.30 \mathrm{dA}$ & $170.77 \mathrm{eA}$ & $156.21 \mathrm{dA}$ \\
\hline IPB-038 & $7907.09 \mathrm{aA}$ & $4693.72 \mathrm{bB}$ & $4574.22 \mathrm{eB}$ & $232.28 \mathrm{bA}$ & $236.34 \mathrm{cA}$ & $154.32 \mathrm{~dB}$ \\
\hline $\begin{array}{c}\text { Brazlândia } \\
\text { Branca }\end{array}$ & $6492.12 \mathrm{aA}$ & $3750.20 \mathrm{bB}$ & $5556.17 \mathrm{dA}$ & $179.51 \mathrm{cA}$ & $134.40 \mathrm{eB}$ & $129.03 \mathrm{eB}$ \\
\hline Palmas & $8211.77 \mathrm{aA}$ & $5829.62 \mathrm{bB}$ & $8145.67 \mathrm{cA}$ & $296.05 \mathrm{aA}$ & $244.99 \mathrm{cB}$ & $261.77 \mathrm{bB}$ \\
\hline IPB-054 & $4376.65 \mathrm{bB}$ & $2199.17 \mathrm{bC}$ & $6505.52 \mathrm{dA}$ & $230.35 \mathrm{bA}$ & $189.46 \mathrm{~dB}$ & $216.72 \mathrm{bA}$ \\
\hline IPB-056 & $7261.25 \mathrm{aA}$ & $4295.57 \mathrm{aB}$ & $2924.01 \mathrm{eB}$ & $219.13 \mathrm{bB}$ & $262.36 \mathrm{bA}$ & $153.77 \mathrm{cC}$ \\
\hline $\begin{array}{c}\text { Brazlândia } \\
\text { Rosada }\end{array}$ & $6236.21 \mathrm{aA}$ & $6642.47 \mathrm{aA}$ & 3682.64 eB & $217.46 \mathrm{bA}$ & $192.29 \mathrm{dA}$ & $120.91 \mathrm{eB}$ \\
\hline IPB-065 & $4074.77 \mathrm{bB}$ & $2479.25 \mathrm{bB}$ & $5850.08 \mathrm{dA}$ & $178.91 \mathrm{cA}$ & $189.79 \mathrm{dA}$ & $174.73 \mathrm{dA}$ \\
\hline IPB-072 & $4290.18 \mathrm{bB}$ & $3018.94 \mathrm{bB}$ & $10146.06 \mathrm{bA}$ & $124.53 \mathrm{~dB}$ & $215.70 \mathrm{cA}$ & $227.96 \mathrm{cA}$ \\
\hline IPB-073 & $6523.65 \mathrm{aA}$ & $2234.00 \mathrm{bB}$ & $3822.88 \mathrm{eB}$ & $181.43 \mathrm{cA}$ & $143.77 \mathrm{cB}$ & $105.09 \mathrm{eC}$ \\
\hline IPB-075 & $6498.95 \mathrm{aB}$ & $5910.39 \mathrm{aB}$ & $8516.12 \mathrm{cA}$ & $175.04 \mathrm{cA}$ & $199.98 \mathrm{dA}$ & $134.63 \mathrm{eB}$ \\
\hline IPB-077 & $3979.39 \mathrm{bB}$ & $3653.62 \mathrm{aB}$ & $11998.56 \mathrm{aA}$ & $156.45 \mathrm{dA}$ & $163.48 \mathrm{eA}$ & $181.82 \mathrm{dA}$ \\
\hline IPB-079 & $6020.76 \mathrm{aA}$ & $5843.28 \mathrm{aA}$ & $5127.63 \mathrm{dA}$ & $148.91 \mathrm{~dB}$ & $191.86 \mathrm{dA}$ & $123.14 \mathrm{eB}$ \\
\hline IPB-080 & $4245.20 \mathrm{bB}$ & $2600.55 \mathrm{bB}$ & $7331.42 \mathrm{cA}$ & $144.63 \mathrm{dA}$ & $178.91 \mathrm{dA}$ & $165.79 \mathrm{dA}$ \\
\hline IPB-087 & $5388.03 \mathrm{aA}$ & $6937.63 \mathrm{aA}$ & $5141.85 \mathrm{dA}$ & $151.80 \mathrm{~dB}$ & $191.83 \mathrm{dA}$ & $105.75 \mathrm{eC}$ \\
\hline IPB-091 & $4521.63 \mathrm{bB}$ & $2825.42 \mathrm{bB}$ & $7658.22 \mathrm{cA}$ & $193.71 \mathrm{cA}$ & $156.21 \mathrm{eA}$ & $179.37 \mathrm{dA}$ \\
\hline IPB-095 & $5239.44 \mathrm{aA}$ & $4913.93 \mathrm{aA}$ & $7065.74 \mathrm{cA}$ & $151.48 \mathrm{dA}$ & $186.73 \mathrm{dA}$ & $165.63 \mathrm{dA}$ \\
\hline IPB-099 & $4773.71 \mathrm{bA}$ & $4695.72 \mathrm{aA}$ & $3962.51 \mathrm{eA}$ & $238.37 \mathrm{bA}$ & $205.85 \mathrm{dA}$ & $212.05 \mathrm{cA}$ \\
\hline IPB-114 & $6649.28 \mathrm{aA}$ & $2708.75 \mathrm{bB}$ & $4184.87 \mathrm{eB}$ & $211.69 \mathrm{bA}$ & $229.37 \mathrm{cA}$ & $187.28 \mathrm{~dB}$ \\
\hline IPB-137 & $2478.36 \mathrm{bB}$ & $6351.75 \mathrm{aA}$ & $5582.23 \mathrm{dA}$ & $165.18 \mathrm{dA}$ & $183.69 \mathrm{dA}$ & $156.21 \mathrm{dA}$ \\
\hline IPB-145 & $3464.29 \mathrm{bA}$ & $5868.33 \mathrm{aA}$ & $4902.36 \mathrm{dA}$ & $145.91 \mathrm{~dB}$ & $234.78 \mathrm{cA}$ & $116.71 \mathrm{eB}$ \\
\hline IPB-147 & $5644.87 \mathrm{aB}$ & $3525.20 \mathrm{bB}$ & $6136.10 \mathrm{dA}$ & $216.89 \mathrm{bA}$ & $221.00 \mathrm{cA}$ & $162.62 \mathrm{~dB}$ \\
\hline IPB-149 & $5105.24 \mathrm{aB}$ & $4501.57 \mathrm{aB}$ & $9662.91 \mathrm{bA}$ & $278.49 \mathrm{aA}$ & $192.80 \mathrm{~dB}$ & $293.70 \mathrm{aA}$ \\
\hline IPB-151 & $6028.21 \mathrm{aA}$ & $3680.76 \mathrm{bA}$ & $4302.68 \mathrm{eA}$ & $209.14 \mathrm{bA}$ & $165.57 \mathrm{eB}$ & $159.06 \mathrm{~dB}$ \\
\hline IPB-158 & $6321.99 \mathrm{aA}$ & $1475.64 \mathrm{bB}$ & $3317.20 \mathrm{eB}$ & $267.52 \mathrm{aA}$ & $194.75 \mathrm{~dB}$ & $168.95 \mathrm{~dB}$ \\
\hline IPB-159 & $2249.11 \mathrm{bA}$ & $2966.99 \mathrm{bA}$ & $2821.55 \mathrm{eA}$ & $204.82 \mathrm{bB}$ & $283.02 \mathrm{bA}$ & $193.91 \mathrm{~dB}$ \\
\hline IPB-162 & $6936.57 \mathrm{aA}$ & $4193.34 \mathrm{aB}$ & $3701.16 \mathrm{eB}$ & $253.24 \mathrm{aB}$ & $310.42 \mathrm{aA}$ & $150.72 \mathrm{dC}$ \\
\hline $\mathrm{CV}(\%)$ & 21.50 & 27.05 & 25.97 & 9.43 & 12.32 & 6.51 \\
\hline
\end{tabular}

Means followed by the same lowercase letter in the columns and uppercase letter in the rows do not significantly differ by the ScottKnott test $(p \leq 0.05) ; \mathrm{SC}=$ São Cristóvão; MA = Malhador; CA = Canindé do São Franscisco

\section{Joint analysis and genetic parameters}

According to the analysis of variance (Table

5), difference in the genotype $x$ environment interaction (GxA) was observed for all variables, which indicates variability in selecting the most productive materials. 
Table 5. Summary of the analysis of covariance of the following variables: root dry matter content (RDMC), root starch content (SC), starch yield (SY), ethanol yield (EY), and ethanol yield per ton of root (EYR), for 31 sweet potato clones grown in three municipalities of the state of Sergipe, Brazil.

\begin{tabular}{lcccccc}
\hline & & \multicolumn{5}{c}{ QM } \\
\cline { 2 - 7 } Source of variance & DF & RDMC & SC & SY & EY & EYR \\
\hline Blocks/Environments & 6 & 9.59 & 2.15 & 6.03 & 7106344.48 & 253.08 \\
Genotypes (G) & 30 & $80.13^{* *}$ & $86.88^{* *}$ & $9.34^{* *}$ & $11011154.18^{* * *}$ & $10242.91^{* *}$ \\
Environments (A) & 2 & $1025.53^{* *}$ & $204.55^{* *}$ & $82.25^{* *}$ & $100507823.83^{* *}$ & $24116.56^{* *}$ \\
G x A & 60 & $15.15^{* *}$ & $31.40^{* *}$ & $9.87^{* *}$ & $11639769.29^{* *}$ & $3702.27^{* *}$ \\
Error & 180 & 8.72 & 3.07 & 1.40 & 1652377.33 & 362.48 \\
\hline CV $(\%)$ & & 9.07 & 10.01 & 25.05 & 25.05 & 10.01 \\
\hline
\end{tabular}

$*, * *$ Significance at $5 \%$ and $1 \%$, respectively, by the $\mathrm{F}$ test.

The degree of variability within the measured variables differed within each environment, with small reduction in RDMC in São Cristóvão; small reduction in RDMC and EYR in Malhador; and small reduction in RDMC in Canindé de São Francisco (Table 5). Azevedo et al. (2014) observed the influence of the genotype $x$ environment interaction only for starch content. In the present work, this influence was observed for all the studied variables.
For Malhador, the highest $\mathrm{CV}_{\mathrm{g}}$ values were observed for RDMC. Canindé de São Francisco had the highest $\mathrm{CV}_{\mathrm{g}}$ values for SC, SY, EY, and EYR, indicating the presence of greater variation for these traits, when compared with the other variables.

In the present experiment, the values of $\mathrm{CV}_{\mathrm{g}} / \mathrm{CV}_{\mathrm{e}}$ ratio for $\mathrm{RDMC}, \mathrm{SC}$, and EYR were high $(0.91,1.42$, and 1.42 , respectively), justifying their use in the genetic improvement process (Table 6).

Table 6. Genetic parameters for joint analysis and in each environment: root dry matter content (RDMC), root starch content (SC), starch yield (SY), ethanol (EY), and ethanol yield per ton of root (EYR), for 31 sweet potato clones grown in three municipalities of the state of Sergipe, Brazil.

\begin{tabular}{lccccc}
\hline Joint analysis & RDMC & SC & SY & EY & EYR \\
\hline Genetic variance & 7.22 & 6.16 & -0.06 & -69841.15 & 726.74 \\
Residual variance & 8.72 & 3.07 & 1.40 & 1652371.23 & 362.48 \\
$\mathrm{~h}^{2} \%$ (mean) & 81.09 & 63.85 & -5.71 & -5.71 & 63.86 \\
$\mathrm{CV}_{\mathrm{g}}(\%)$ & 8.26 & 14.17 & 0.00 & 0.00 & 14.17 \\
$\mathrm{CV}_{\mathrm{e}}(\%)$ & 9.08 & 9.98 & 0.00 & 0.00 & 9.98 \\
$\mathrm{CV}_{\mathrm{g}} / \mathrm{CV}_{\mathrm{e}}$ ratio & 0.91 & 1.42 & 0.00 & 0.00 & 1.42 \\
\hline Municipalities & $\mathbf{R D M C}$ & $\mathbf{S C}$ & $\mathbf{S Y}$ & $\mathbf{E Y}$ & $\mathbf{E Y R}$ \\
\hline & & & $\mathbf{C V} \mathbf{g}(\mathbf{\%})$ & \\
São Cristóvão & 9.01 & 21.18 & 26.15 & 26.15 & 21.18 \\
Malhador & 10.48 & 18.05 & 34.71 & 34.71 & 18.05 \\
Canindé de São Francisco & 8.88 & 28.78 & 40.17 & 40.17 & 28.78 \\
\hline & & & & \\
São Cristóvão & 73.87 & 93.81 & 81.61 & 81.61 & 93.81 \\
Malhador & 69.52 & 86.57 & 83.16 & 83.16 & 86.57 \\
Canindé de São Francisco & 88.7 & 98.32 & 87.77 & 87.77 & 98.32 \\
\hline
\end{tabular}

$\mathrm{h}^{2}$ : mean heritability; $\mathrm{CV}_{\mathrm{g}}$ : coefficient of genetic variation; $\mathrm{CV}_{\mathrm{e}}$ : coefficient of environmental variation.

For ethanol biofuel production in the three environments, cultivar Palmas and clones IPB-075 and IPB-087 presented the best performance for the following traits: RDMC, SY, and EY.

$\mathrm{h}^{2}$ estimates were above $50 \%$ for all variables, demonstrating that this trait is highly influenced by the environment and is not a good indicator of the genotypic value (Table 6). According to Cruz (2005), high $\mathrm{h}^{2}$ values indicate that genetic differences are responsible for the variations in traits, whereas low $\mathrm{h}^{2}$ values indicate that much of the variation is due to environmental differences among individuals. High $h^{2}$ values indicate that the traits have strong genetic control and great potential to be transferred to future generations.

All of the traits, except for SY, and EY, presented high heritability, indicating that the traits have strong genetic control and great potential to be transferred to future generations. With this, the best- 
selected individuals in these environments have tendency to transfer their yield levels to the next generations, maintaining the same yield levels (Table 6).

$\mathrm{CV}_{\mathrm{g}} / \mathrm{CV}_{\mathrm{e}}$ ratio can be used as an index for the degree of ease in selecting progeny for each trait; when the ratio estimate is equal to or greater than 1.0, the situation is very favorable for the selection process, that is, the available genetic variation is responsible for the estimated $\mathrm{CV}$ values of the experimental data (YOKOMIZO; FARIAS NETO, 2003).
IPB-077 clone had EY value of 11998.56 L $\mathrm{ha}^{-1}$ in a 6-month cycle, which is higher than that of sugarcane.

Variability within and between environments was observed for all variables. For ethanol biofuel production, cultivar Palmas and clones IPB-075 and IPB-087 presented the best performance in the three environments.

\section{ACKNOWLEDGEMENTS}

The authors thank FAPITEC/SE, CNPq, and CAPES for their financial support for this work.

RESUMO: A batata doce é uma espécie pertencente a família Convolvulaceae, originária da América Central e do Sul. As condições de cultivo têm grande influência na produção, sendo que a determinação do tempo de colheita varia de acordo com a cultivar, com a região de cultivo e com a forma de consumo (in natura ou industrial). O objetivo deste trabalho foi avaliar o desempenho de clones de batata-doce (Ipomoea batatas L.) cultivados em três regiões do estado de Sergipe para produção de amido e etanol. Testou-se, em delineamento de blocos casualizados, 31 genótipos de batata doce em três município do Estado de Sergipe. As características analisadas foram: teor de matéria seca de raízes (RDMC), teor de amido nas raízes (SC), rendimento de raízes (SY), rendimento de etanol (EY) e rendimento de etanol por tonelada de raiz (EYR). Os valores de EY variaram de 5910,39 a 8516,12 L.ha ${ }^{-1}$, de 5141,85 a 6937,63 L ha ${ }^{-1}$ e de 5829,62 a 8211,77 $\mathrm{L} \mathrm{ha}^{-1}$ para São Cristóvão, Malhador e Canindé de São Francisco, respectivamente, para os clones IPB-075 e IPB-087 e a cultivar Palmas. As estimativas de herdabilidade $\left(\mathrm{h}^{2}\right)$ foram superiores a $50 \%$. Os valores da razão entre o coeficiente de variação genotípica e o ambiental para RDMC, SC, e EYR foram altos.

PALAVRAS-CHAVE: Ipomoea batatas. Herdabilidade. Biocombustível. Parâmetros genéticos

\section{REFERENCES}

AZEVEDO, A. M.; ANDRADE JÚNIOR, V. C.; VIANA, D. J. S.; ELSAYED, A.; PEDROSA, C. E.; NEIVA, I. P.; FIGUEIREDO, J. A. Influence of harvest time and cultivation sites on the productivity and quality of sweet potato. Horticultura Brasileira, Brasília, v. 32, P. 21-27, 2014. https://doi.org/10.1590/S010205362014000100004

BARRETO, H. G.; SANTOS, L. B.; OLIVEIRA, G. I. S.; SANTOS, G. R.; FIDELIS, R. R.; SILVEIRA, M. A.; NASCIMENTO, I. R. Estabilidade e adaptabilidade da produtividade e da reação a insetos de solo em genótipos experimentais e comerciais de batata-doce. Revista Brasileira de Biociência, Porto Alegre, v. 27, p. 739-747, 2011.

CASTRO, I. P. M.; ALVIM, T. C.; SANTANA, W. R.; CARVALHO, V. D. P.; SILVEIRA, M. A. Efeito da adição de soro de queijo no processo de obtenção de etanol a partir de batata-doce. Ciência e Agrotecnologia, Lavras, v. 35, p. 980-986, 2011.

CAVALCANTE, M.; FERREIRA, P. V.; PAIXÃO, S. L; COSTA, J. G.; PEREIRA, R. G.; MADALENA, J. A. Potenciais produtivo e genético de clones de batata-doce. Acta Scientiarum Agronomy, Maringá, v. 31, p. 421-426, 2009. https://doi.org/10.4025/actasciagron.v31i3.835

CRUZ, C. D. Princípios de genética quantitativa. 1a. ed. Viçosa: UFV, 2005. 391 p.

CRUZ, C. D. GENES - a software package for analysis in experimental statistics and quantitative genetics. Acta Scientiarum. Agronomy, Maringá, v. 35, n. 3, 2013. 
GONÇALVES NETO, A. C.; MALUF, W.R.; GOMES, L. A. A.; GONÇALVES, R. J. S.; SILVA, V. F.; LASMAR, A. Aptidões de genótipos de batata-doce para consumo humano, produção de etanol e alimentação animal. Pesquisa Agropecuária Brasileira, Brasília, v. 46, p. 1513-1520, 2011.

IAL (INSTITUTO ADOLFO LUTZ). Métodos físico-químicos para análise de alimentos. 4ed. São Paulo: IAL, 2008. 1018p.

PAVLAK, M. C. M.; ABREU-LIMA, T. L.; CARREIRO, S. C.; PAULILLO, S. C. L. Estudo da fermentação do hidrolisado de batata-doce utilizando diferentes linhagens de Saccharomyces cerevisiae. Química Nova, São Paulo, v. 34, p. 82-86, 2011. https://doi.org/10.1590/S0100-40422011000100016

QUEIROGA, R. C. F; SANTOS, M. A.; MENEZES, M. A.; VIEIRA, C. P. C.; SILVA, M. C. Fisiologia e produção de cultivares de batata-doce em função da época de colheita. Horticultura Brasileira, Brasília, v. 25, p. 371-374, 2007. https://doi.org/10.1590/S0102-05362007000300010

RIBEIRO, N.; GODINHO, A. M. M.; MARQUES, T. A. Produção de glicose a partir do amido da batata-doce por hidrólise ácida. Colloquium Agrariae, Presidente Prudente, v. 5, p. 242-263, 2009.

SILVA, J. B. C.; LOPES, C. A.; MAGALHÃES, J. S. Cultura da batata-doce. In: CEREDA, M. P. (Ed.). Agricultura: tuberosas amiláceas latino americanas. Cargill, São Paulo. 2002. p. 448 - 504.

SILVA, J. B. C.; LOPES, C. A.; MAGALHÃES, J. S. Cultura da batata-doce. Brasília: Embrapa Hortaliças, 2004. (Sistema de produção 6).

SILVEIRA, M. A. Cultura da batata-doce como fonte de matéria-prima para o etanol. Palmas: UFTO, 2007. 64p.

VENCOVSKY, R.; BARRIGA, P. Genética biométrica no fitomelhoramento. Ribeirão Preto: SBG, 1992. 496p.

VIEIRA, A. D.; MIRANDA, V. C.; ALVES, A. F.; TAVARES, A. T.; MOMENTÉ, V. G. Avaliação agronômica de clones de batata doce com potencial para produção de etanol. Applied Technology for Agricultural Science, Guarapuava, v. 8, p. 69-74, 2015.

YOKOMIZO, G. K.; FARIAS NETO, J. T. de. Caracterização fenotípica e genotípica de progênies de pupunheira para palmito. Pesquisa Agropecuária Brasileira, Brasília, v. 38, p. 67-72, 2003.

https://doi.org/10.1590/S0100-204X2003000100009 